\title{
Polyculture of all-male tilapia hybrids with low densities of Macrobrachium rosenbergii'
}

\author{
Andrew S. McGinty and Dallas E. Alston ${ }^{2}$
}

\begin{abstract}
Each of six $700-\mathrm{m}^{2}$ earthen ponds was stocked with all-male hybrid fingerlings $(28 \mathrm{~g})$ from the cross of female rilapia nilotica $\times$ male $T$, hornorum, at a rate of $0.4 \mathrm{fish} / \mathrm{m}^{2}$. Six days later, duplicate ponds were stocked with either $0.5,1.0$ or 1.5 juvenile prawns (Macrobrachium rosenbergii) $(2 \mathrm{~g})$ per $\mathrm{m}^{2}$. Initially $32 \%$ protein pellets were fed daily at $2.5 \%$ of fish biomass; this ratio was decreased to $1.4 \%$ by harvest. At the low, medium and high prawn densities, average yields after 20 weeks were 171,243 , and $350 \mathrm{~kg} / \mathrm{ha}$ for prawns and 1,$404 ; 1,450$; and $1,356 \mathrm{~kg} / \mathrm{ha}$ for tilapia, respectively. At these densities, $84.4,87.7$, and $85.4 \%$ of the prawns weighed $30 \mathrm{~g}$ or more, whereas $75.0,67.5$, and $71.3 \%$ weighed $40 \mathrm{~g}$ or more, respectively. Average weight of tilapia was $395 \mathrm{~g}$ among all ponds, independent of prawn density.
\end{abstract}

\section{INTRODUCTION}

Tilapia are an important food fish for culture, particularly in the tropics. Depending on desired market size and management, final growout in ponds generally lasts 4 to 7 months, at which time ponds are usually drained and completely harvested (5).

Prawns (Macrobrachium rosenbergii) are also an important species for culture. In the tropics, management often uses continuous culture in which market-size prawns are selectively harvested over extended periods. Juveniles are then stocked to replace the harvested prawns (8). Often harvest efficiency is low; therefore, labor costs increase (6). Thus, to rear prawns with tilapia, shorter culture periods with complete harvests may be preferable.

The polyculture of prawns and tilapia has revealed no negative interactions $(1,3,7)$. In each of these previous studies, either prawns, tilapia, or both were relatively small at harvest because of small initial sizes, high stocking densities, short culture periods, or a combination of these factors. For successful tilapia/prawn polyculture in ponds with complete harvest, it is important to synchronize attainment of market size by both species. Thus, our study was designed to determine the effects of prawn stocking density on final size and yields of prawns and tilapia reared in ponds for 19 and 20 weeks, respectively.

${ }^{\mathrm{I}}$ Manuscript submitted to Editorial Board March 25, 1986.

${ }^{2}$ Department of Marine Sciences, University of Puerto Rico, Mayagüez, P. R. 00709. The authors thank William Rosado for his assistance with the field work. This study was partially funded by H-342-3 and -4 for the Warmwater Aquaculture regional projects S-168. 


\section{MATERIALS AND METHODS}

This study was conducted at the Aquaculture Field Station, Department of Marine Sciences, in conjunction with the Lajas Agricultural Research and Development Center of the University of Puerto Rico in six earthen $700-\mathrm{m}^{2}$ ponds. On 19 October 1983 (day 0 ), each pond was stocked with all-male hybrid fingerlings $(28 \mathrm{~g})$ of female Tilapia nilotica $\mathrm{x}$ male T. hornorum at a rate of $0.4 \mathrm{fish} / \mathrm{m}^{2}$, and then 6 days later with either $0.5,1.0$ or $1.5 / \mathrm{m}^{2}$ of juvenile prawns (table 1 ).

Feeding was based on the sole criterion of fish biomass. All fish were fed $32 \%$ protein, sinking pellets, twice daily in two equal portions. Feeding rates (\% fish biomass) were adjusted on the basis of monthly sampled weights. Initial feeding rate was $2.5 \%$ per day; it decreased to $1.4 \%$ by harvest (day 140).

At harvest, tilapia were counted and weighed collectively, whereas prawns were individually weighed by morphotype and sex. Morphotypes included blue-claw males, orange-claw males, small males, females with eggs and females without eggs (4).

\section{RESULTS AND DISCUSSION}

Table 1 summarizes harvest data. Increasing prawn density had little effect on their average weight at harvest; therefore, yield increased with increasing prawn stocking density $(r=0.730 ; \mathrm{P}<0.1)$. This relationship would have been closer had survival rates been more consistent. Survival of prawns was not significantly $(\mathrm{P}>0.1)$ related to prawn stocking density. One pond each from the medium and high prawn density had lower prawn survival than the others; however, this was attributed to predation by wading birds observed during draining and was not a density effect. Subsequently, to prevent recurrence of this problem, we guarded all remaining ponds during draining.

Among morphotypes, blue-claw males showed the greatest response to changes in density (table 2). Cohen and Ra'anan (3) found more pronounced inverse relationships between density and average weights at harvest. This was likely a result of the smaller initial prawn size (1 vs. $2 \mathrm{~g}$ ) and shorter grow-out (90 vs. 134 days) in their study. At each density the average weight of male prawns was greater than that of females.

The proportion of females increased $(r=0.925$; $\mathrm{P}<0.01)$ with increasing prawn density. This is the opposite of findings by Cohen and $\mathrm{Ra}^{\prime}$ anan (3) for prawns cultured with tilapia. Interestingly, in our study, the frequency of occurrence of females with eggs was also positively correlated with prawn density ( $r=0.743 ; \mathrm{P}<0.1$ ), but was inversely related to density in their study (3). Once again this may be related to the larger initial size and longer grow-out period in the present study. Cohen and Ra'anan (3) suspected that fewer females than males reached the 
TABLE 1.--Production data for prawns and all-male tilapia hybrids reared 20 weeks in ponds

\begin{tabular}{|c|c|c|c|c|c|c|c|c|c|}
\hline \multirow{2}{*}{$\begin{array}{l}\text { Stocking } \\
\text { density } \\
\text { no. } / \mathrm{m}^{2}\end{array}$} & \multirow[b]{2}{*}{ Pond no. } & \multicolumn{2}{|c|}{$\begin{array}{l}\text { Mean weight at } \\
\text { stocking }(g)\end{array}$} & \multicolumn{2}{|c|}{$\begin{array}{l}\text { Mean weight at } \\
\text { harvest }(\mathrm{g})\end{array}$} & \multicolumn{2}{|c|}{ Yield } & \multicolumn{2}{|c|}{ Survival } \\
\hline & & Prawns & Tilapia & Prawns & THlapia & Prawns & Tilapia & Prawns & Tilapia \\
\hline & & & & & & \multicolumn{2}{|c|}{$\mathrm{kg} / \mathrm{ha}$} & \multicolumn{2}{|c|}{$\%$} \\
\hline 0.5 prawns & 1 & 2.0 & 29.4 & 49 & 374 & 181 & 1362 & 74 & 91 \\
\hline \multirow[t]{2}{*}{0.4 tilapia } & 6 & 2.2 & 26.2 & 41 & 400 & 162 & 1446 & 78 & 91 \\
\hline & Average & 2.1 & 27.8 & 45 & 387 & 171 & 1404 & 76 & 91 \\
\hline 1.0 prawns & 5 & 2.2 & 29.8 & 39 & 422 & 276 & 1537 & 70 & 91 \\
\hline \multirow[t]{2}{*}{0.4 tilapia } & 2 & 2.2 & 26.5 & 41 & 401 & 210 & 1362 & $51^{1}$ & 92 \\
\hline & Average & 2.2 & 28.2 & 40 & 412 & 243 & 1450 & 60 & 92 \\
\hline 1.5 prawns & 4 & 1.9 & 29.4 & 42 & 354 & 463 & 1301 & 74 & 92 \\
\hline \multirow[t]{2}{*}{0.4 tilapia } & 3 & 2.1 & 26.3 & 36 & 420 & 238 & 1410 & $44^{1}$ & 90 \\
\hline & Average & 2.0 & 27.9 & 39 & 387 & 351 & 1356 & 59 & 91 \\
\hline
\end{tabular}

${ }^{1}$ Unguarded during draining; observed high predation by wading birds.

TABLE 2.-Average body weight and percentage frequency of occurrence by morphotypes of prawns reared at three densities with tilapia hybrids ${ }^{1}$

\begin{tabular}{|c|c|c|c|c|c|c|c|c|}
\hline \multirow{3}{*}{$\begin{array}{c}\text { Prawns per } \\
\mathrm{m}^{2}\end{array}$} & \multirow[b]{3}{*}{ Pond no. } & \multicolumn{7}{|c|}{ Average weight $(\mathrm{g})$-Frequency $(\%)$} \\
\hline & & \multicolumn{4}{|c|}{ Males } & \multicolumn{3}{|c|}{ Females } \\
\hline & & Small & Orange-claw & Blue-claw & Total & With eggs & Without eggs & Total \\
\hline \multirow{2}{*}{0.5} & 6 & $12.2-16.8$ & $48.0-24.1$ & $95.5-10.2$ & $45.7-51.1$ & $39.3-9.5$ & $35.9 \sim 39.4$ & $36.6-48.9$ \\
\hline & Mean & $12.8-13.4$ & $51.6-25.9$ & $95.6-11.5$ & $51.4-50.8$ & $39.2-10.1$ & $38.2-39.1$ & $38.3-49.2$ \\
\hline \multirow[t]{2}{*}{1.0} & 5 & $15.8-12.6$ & $42.9-19.3$ & $70.3-16.7$ & $45.3-48.7$ & $35.9-13.2$ & $33.1-38.1$ & $33.8-51.3$ \\
\hline & 2 & $14.2-13.0$ & $51.6-26.2$ & $89.9-9.0$ & $48.7-48.2$ & $37.3-16.1$ & $33.6-35.8$ & $34.7-51.8$ \\
\hline \multirow{2}{*}{1.5} & 3 & $11.3-16.6$ & $42.8-16.6$ & $84.0-10.3$ & $40.6-43.4$ & $35.2-16.8$ & $30.4-39.8$ & $32.1-56.6$ \\
\hline & Mean & $12.0-11.9$ & $45.0-23.7$ & $81.2-9.4$ & $44.0-45.0$ & $37.8-14.9$ & $33.6-40.1$ & $34.6-55.0$ \\
\hline
\end{tabular}

${ }^{1}$ Tilapia hybrids stocked at $0.4 / \mathrm{m}$. $^{2}$ 
minimum size for sexual maturation. Because of stocking larger juveniles in our study, differential rates of maturation may have been lessened, thereby decreasing possible negative interactions between mature males and immature females. We found a higher percentage of females with eggs than Cohen and Ra'anan reported. There were no significant effects $(\mathrm{P}>0.1)$ of prawn density on frequency of occurrence of other morphotypes.

A high proportion of prawns were of a marketable size at harvest. At the low, medium, and high prawn densities, $84.4,87.7$, and $85.4 \%$ of prawns weighed $30 \mathrm{~g}$ or more, whereas $75.0,67.5$, and $71.3 \%$ weighed $40 \mathrm{~g}$ or more, respectively. Brody et al. (2) reported that a considerably lower percentage of prawns attained $30 \mathrm{~g}$ or more when reared in monoculture at higher densities for 6 or 7 months. They suggested early selective harvest as one way to improve commercial yields. At the densities we tested, early selective harvests to remove larger prawns would hardly be worthwhile because of increased labor costs.

There appeared to be no adverse interactions beteen prawns and tilapia. Yield, average weight and survival of tilapia were independent of prawn density (table 1). This concurs with previous findings $(1,3,7)$.

In conclusion, our results agree with previous findings that no adverse interactions occur between prawns and fish reared together. In a 20-week grow-out period at the highest prawn density tested in our study, a high percentage of prawns and tilapia attained the desired market sizes of about 35 and $400 \mathrm{~g}$, respectively. For semi-intensively managed ponds to be completely harvested every 5 to 6 months, we recommend stocking 1.5 to 2.5 juvenile prawns and 0.8 to 1.0 male tilapia fingerlings per square meter.

\section{RESUMEN}

Policultivo de híbridos machos de tilapia a bajas densidades de Macrobrachium rosenbergii

En 6 estanques de tierra de $700 \mathrm{~m}^{2}$ cada uno se sembraron alevines machos híbridos de $28 \mathrm{~g}$. de Tilapia nilotica hembra $\times T$. hornorum macho, a razón de 0.4 peces $/ \mathrm{m}^{2}$. Estos mismos estanques se sembraron (en duplicado) 6 días después, con 0.5, 1.0, ó 1.5 camarones (Macrobrachium rosenbergii) juveniles de $2 \mathrm{~g}$. por $\mathrm{m}^{2}{ }^{2}$, respectivamente. Inicialmente, se les suministró alimento en perdigones que contenían $32 \%$ de proteína a $2.5 \%$ de la biomasa de pez que se disminuyó diariamente hasta $1.4 \%$ al momento de la cosecha. Para la densidad baja, mediana y alta, respectivamente, la producción media de camarones al cabo de $\mathbf{2 0}$ semanas fue de 171,243 y $350 \mathrm{~kg} . / \mathrm{ha}$. y de 1404,1450 y $1356 \mathrm{~kg}$./ha. de filapia por hectárea. A esas mismas densidades, $84.4,87.7$, y $85.4 \%$ de los camarones pesaron $30 \mathrm{~g}$. O más, mientras que $75.0,67.5$ y $71.3 \%$, respectivamente, pesaron $\mathbf{4 0} \mathrm{g}$. 0 más al cosechar. 


\section{LITERATURE CITED}

1. Brick, R. W. and R. R. Stickney, 1979. Polyculture of Tilapia aurea and Macrobrachium rosenbergii in Texas. Proc. World Mariculture Soc. 10: 222-28.

2. Brody, T. D., D. Cohen, A. Barnes and A. Spector, 1980. Yield characteristics of the prawn Macrobrachium rosenbergii in temperate zone aquaculture. Aquaculture 21: 375-85.

3. Cohen, D. and Z. Ra'anan, 1983. The production of the freshwater prawn Macrobrachium rosenbergii in Israel. III. Density effect of all-male Tilapia hybrids on prawn yield characters in polyculture. Aquaculture 35: 57-71.

4. Cohen, D., Z. Ra'anan and T. Brody, 1981. Population profile development and morphotypic differentiation in the giant freshwater prawn Macrobrachium rosenbergii (de Man). J. World Marieulture Soc. 12 (2): 231-43.

5. Hepher, B. and Y. Pruginin, 1982. Tilapia culture in ponds under controlled conditions. p. 185-203. IN R. S. V. Pullin and R. H. Lowe-McConnell (Eds). The biology and culture of tilapias. ICLARM Conference Proc. 7, 432 p. Int. Center Living Aquat. Res. Manage., Manila, Philippines.

6. Malecha, S. R., J. Polovina and R. Moav, 1981. Multi-stage rotational stocking and harvesting system for year-round culture of the freshwater prawn, Macrobrachizm rosenbergii. UNIHI-SEAGRANT-TR-81-01, Univ. Hawaii Sea Grant College Program, Honolulu.

7. Rouse, D. B. and R. R. Stiekney, 1982. Evaluation of the production potential of Macrobrachium rosenbergii in monoculture and in polyculture with Tilapia aurea. J. World Mariculture Soc. 13: 73-85.

8. Wang, J.-K. and M. R. Williamson, 1980. Aquacultural engineering in fresh water prawn production. Am. Soc. Agric. Eng. 23 (5): 1318-325. 